\title{
DENTAL FLUOROSIS KNOWLEDGE AND PERCEPTION AMONG STUDENTS OF THE HEALTH SCIENCES
}

DSMJ;19(2); 1-3

http://dx.doi.org/10.4314/dmsj.v19i2.1

Daniel Shunu, DDS2

Institution: Muhimbili University of Health and Allied Sciences (MUHAS)

\section{ABSTRACT}

Introduction: The effect of excessive intake of fluoride is obviously seen among people in endemic areas of fluorosis in Tanzania but people have not openly expressed what they feel about of dental fluorosis.

Objective: To assess dental fluorosis perception among students of the health sciences at Muhimbili University of Health and Allied Sciences (MUHAS).

Materials and methods: A cross-sectional study among students of the health sciences at MUHAS was conducted in April 2012. A total of 40 students aged 19-28 years from different courses were involved to assess their views using a self-administered questionnaire and tables were prepared using Microsoft excel.

Results: thirty students, which is $75 \%$ of all students interviewed were bothered by brown mottled teeth, while the remaining $10(25 \%)$ responded that having brown mottled teeth was normal to them.

A total of 31(77.5\%) didn't know how to prevent dental fluorosis while 9(22.5\%) had knowledge on the effect of excess fluoride so they also knew how to prevent fluorosis.

Conclusion: Majority of the students perceived dental fluorosis as a problem while few had knowledge on how to prevent it. This shows a need to educate them about fluorosis to put them in a better position to combat this problem.

Correspondence to: Daniel Shunu, DDS student, Muhimbili University of Health and Allied Sciences. E-mail: kingudanielshunu@yahoo.com

\section{INTRODUCTION}

Fluorosis is a condition caused by excessive intake of fluoride and is marked by mottling of teeth and damaging of bone ${ }^{(4)}$.

Dental fluorosis is caused by chronic ingestion of fluoride that creates significant enamel defects ${ }^{(5)}$. The critical period for clinically significant dental fluorosis occurs during the second and third years of life when dental hard tissues are formed and during fetal development when a mother takes excess fluoride ${ }^{(4)}$. Usually moderate defects can be seen when drinking water contains $1.5 \mathrm{mg} /$ litre equivalent to $2 \mathrm{ppm}$ of fluoride in water while severe defects of enamel can be caused by $3.6 \mathrm{mg} /$ litre equivalent to $4.8 \mathrm{ppm}$. However, a low concentration of $1 \mathrm{ppm}$ is good for strengthening bone and teeth ${ }^{(5)}$.

Studies done in Tanzania on fluoride concentration in water by region are as follows (permission obtained from Vuhahula et al)

\section{AIM AND JUSTIFICATION OF THE STUDY}

The aim of the study is to know how much students of the health sciences know about and how they perceive Dental Fluorosis. This will help in providing knowledge to them so that they are made aware of the problem and can effectively provide health education.

A similar study has been conducted on school children in Kenya ${ }^{(2)}$ where about $84 \%$ of subjects disliked the effects of dental fluorosis.
However, no study has been conducted among students of the health sciences who are expected to play a role in combating the problem.

\section{STUDY OBJECTIVE}

Broad objective:

The main objective of this study was to assess knowledge and perception of dental fluorosis among students of the health sciences at MUHAS

Specific objective:

To assess knowledge of students on prevention of dental fluorosis

To assess perception of students on dental fluorosis

\section{METHODOLOGY}

The study was conducted in April 2012 at Muhimbili University of Health and Allied Sciences in Dar es salaam, Tanzania. 40 subjects were involved in the study because only 20 people having dental fluorosis were found and were interviewed first then 20 subjects without dental fluorosis were selected using the simple random method from different courses including diploma and undergraduate students.

Study design: Descriptive Cross-sectional study

Ethical issues: Permission was obtained from the School of Dentistry of MUHAS but consent from individual participants was also obtained.

Data collection: Data were collected using self-administered questionnaires and tables were prepared using Microsoft excel.

Result dissemination: Results were disseminated to students of the health sciences at MUHAS. 

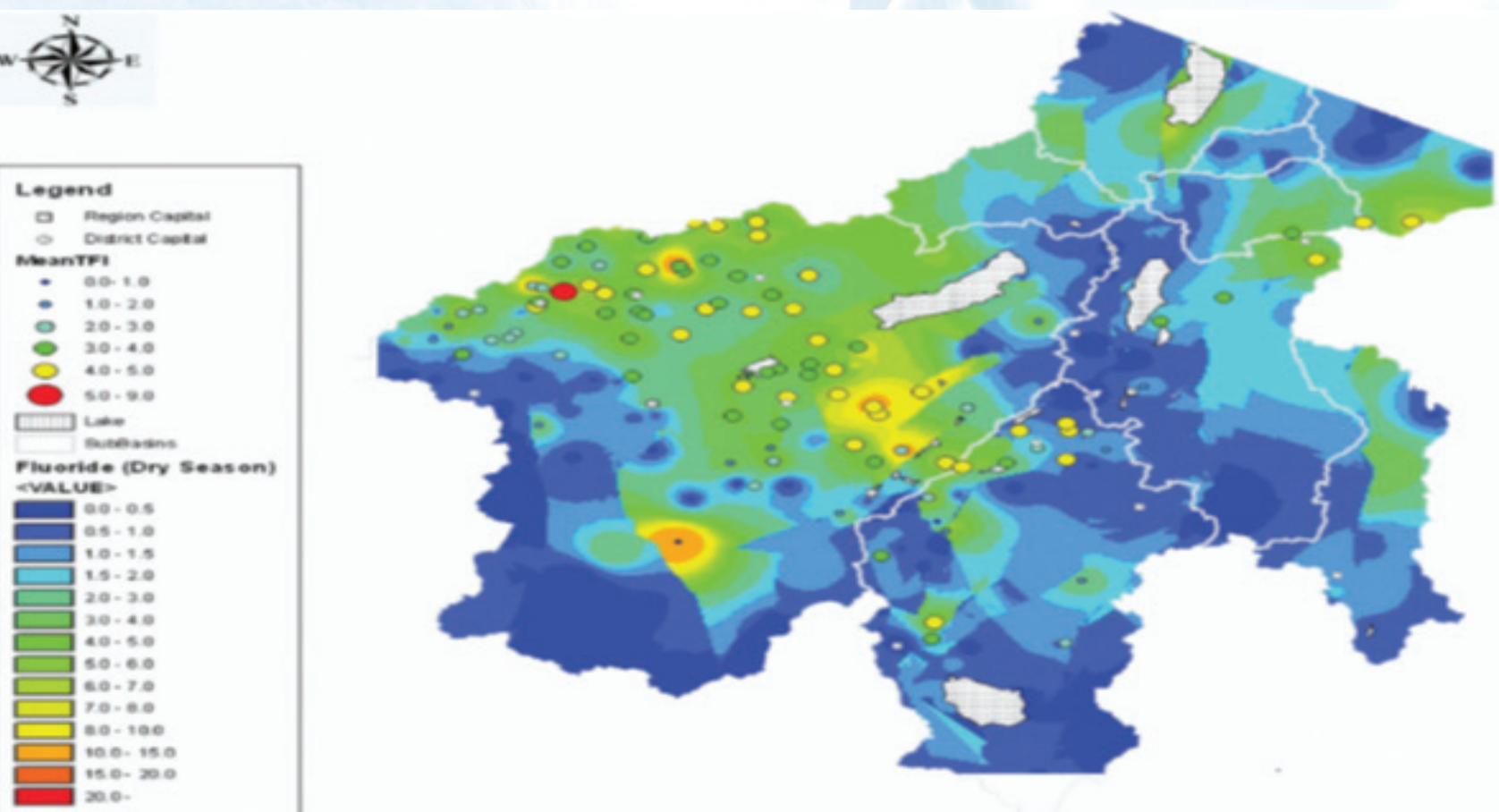

Fig 1 showing water fluoride concentration in different parts of Tanzania

Water is the main way of ingesting excess fluoride through cooked food or beverages. Other ways include salt, milk, magadi, tea and fish ${ }^{(5)}$.

Table 1a

\begin{tabular}{|l|l|l|}
\hline REGIONS & RANGE (F ion) & $\mathrm{mg} /$ liters \\
\hline & minimum & maximum \\
\hline Arusha & 2 & 7.1 \\
\hline Dodoma & 1.5 & 2.5 \\
\hline Manyara & 1.5 & 4 \\
\hline Singida & 1.5 & 16.1 \\
\hline Shinyanga & 1.5 & 24.9 \\
\hline Tabora & 1.5 & 3 \\
\hline
\end{tabular}

\section{RESULTS}

As shown in Table 1, 14(70\%) students with fluorosis and 16(80\%) without fluorosis were bothered by the condition of having brown teeth as found in dental fluorosis because such teeth are not attractive to them. Mottled teeth make them feel inferior when talking or laughing before other people, and this tends to affect them psychologically. In severe cases the usually brittle teeth can easily fracture even when chewing, creating cavities which result in severe pain. A segment of the students that accounted for $25 \%$ of all the participants in the study were not bothered by brown mottled teeth as in fluorosis because they help identify place of origin and tribe. Likewise, such teeth give the concerned persons their individual identity. It was also mentioned that other people may be attracted by the brown color of the mottled teeth.

With respect to avoidance of fluorosis, $17(85 \%)$ and $14(70 \%)$ of students with and without dental fluorosis respectively said they did not know how to prevent the problem and needed more education to overcome it. On the other hand as shown in Table 2,3(15\%) and 6(30\%) of students with and without dental fluorosis respectively said they knew how to prevent the problem.

Table no 1 showing perception on dental fluorosis

\begin{tabular}{|l|l|l|l|}
\hline GROUP & $\begin{array}{l}\text { Subjects who were } \\
\text { bothered by fluorosis }\end{array}$ & $\begin{array}{l}\text { Subjects who were not } \\
\text { bothered by fluorosis }\end{array}$ & TOTAL \\
\hline Subjects with fluorosis & $14(70 \%)$ & $6(30 \%)$ & $20(100 \%)$ \\
\hline Subjects without fluorosis & $16(80 \%)$ & $4(20 \%)$ & $20(100 \%)$ \\
\hline TOTAL & $30(75 \%)$ & $10(25 \%)$ & $40(100 \%)$ \\
\hline
\end{tabular}


Table no 2 below showing knowledge on prevention of dental fluorosis

\begin{tabular}{|l|l|l|l|}
\hline Group & $\begin{array}{l}\text { Students who didn't } \\
\text { know how fluorosis can } \\
\text { be avoided }\end{array}$ & $\begin{array}{l}\text { Students who knew } \\
\text { how fluorosis can be } \\
\text { avoided }\end{array}$ & Total \\
\hline $\begin{array}{l}\text { Students with dental } \\
\text { fluorosis }\end{array}$ & $17(85 \%)$ & $3(15 \%)$ & $20(100 \%)$ \\
\hline $\begin{array}{l}\text { Students without dental } \\
\text { fluorosis }\end{array}$ & $14(70 \%)$ & $6(30 \%)$ & $20(100 \%)$ \\
\hline Total & $31(77.5 \%)$ & $9(22.5 \%)$ & $40(100 \%)$ \\
\hline
\end{tabular}

\section{DISCUSION}

With respect to avoidance of fluorosis, $17(85 \%)$ and $14(70 \%)$ of students with and without dental fluorosis respectively said they did not know how to prevent the problem. This could be because most participants were still in their earlier years of study (first and second year) in which fluorosis is hardly covered. Most students were also taking courses other than Doctor of Dental Surgery (DDS) hence were less likely to know about the problem.

\section{CONCLUSION AND RECOMMENDATIONS}

A total of 30 (75\%) of students perceived dental fluorosis as a problem while 31 (77.5\%) didn't know fluorosis can be avoided. This shows a need to educate students of the health sciences about fluorosis and about its prevention so as to find ways of combating the problem.

There's need for special initiatives at individual and community dental health promotion.

We should be aggressive against dental fluorosis by using our knowledge to make sure everyone understands the problem.

Policy makers should know that the problem is combatible and provide piped water with low fluoride concentrations. More and larger studies need to be done on perception and knowledge about dental fluorosis in the general Tanzanian population.

\section{ACKNOWLEDGEMENTS}

I thank Dr. Vuhalula et al for allowing me to use table 1a and fig. 1 from their study.

The editors of DMSJ have done a wonderful job in mentoring me and helping me improve my paper.

\section{REFERENCES}

1.Mier, $\mathrm{M}$ et al. Questionnaire on perception of Dental fluorosis. Community Dent Health. Dec 2004; 21(4): 299-305.

2.Mwaniki et al. Endemic Fluorosis in Kenya. Pubmed 1994; 39(7973876): 807-813.

3.Neville B et al.. Oral and Maxillofacial Pathology (3rd ed.). New York: Saunders 2008. ISBN 13: 9781416034353

4.Newbrun, E. Fluoride and Dental caries (3 ed.). San francisco: Springfield. 1978.

5.Vuhahula et al. Dental fluorosis in Great Rift Valley in relation to fluoride level in water and Magadi. Desalination 2010; 252: 193-198 